\title{
THE ASSOCIATION BETWEEN TRADITIONAL HABIT "MENYUNTIL" AND HEALTH STATUS AMONG BATAK KARO WOMEN IN DELI SERDANG, NORTH SUMATERA
}

\author{
Ulina Karo Karo'), Ida Yustina' ${ }^{2}$, Etty Sudaryati²), Fikarwan3) \\ 1)Faculty of Public Health, Universitas Prima Indonesia \\ 2)Faculty of Public Health, Universitas Sumatera Utara \\ 3)Faculty of Social and Political Sciences, Universitas Sumatera Utara
}

\begin{abstract}
Background: Oral tobacco utilization occurs in multiple forms and in various parts of the world, including one in Batak Karo ethnic group North Sumatera, Indonesia. Chewing tobacco is practiced by holding tobacco leaf in the mouth inside the cheek or between the cheek and gum. Smokeless, snuff, or chewing tobacco contains nicotine as well as many known carcinogens. More nicotine is absorbed by chewing tobacco use than by smoking a cigarette. Studies have shown that chewing tobacco use is a risk factor for the development of oral cancers and pre-cancers. Other health risks of chewing tobacco include gum disease, tooth decay and tooth loss, and possible links to other cancers and cardiovascular disease. Little is known, however, about the health effect of tobacco chewing practiced by women of Batak Karo ethnic group in North Sumatera. This study aimed to examine the effect of tobacco chewing (known as "Menyuntil") on health of Batak Karo women in North Sumatera.
\end{abstract}

Subjects and Method: This was a cross-sectional study conducted in Sembahe Village, Karo-karo, North Sumatera, in October 2017. A sample of 100 women was selected for this study by purposive sampling. The dependent variable was maternal health status. The independent variable was the traditional habit tobacco chewing ("menyuntil"). The data were collected by questionnaire and clinical examination. The data were analyzed by Prevalence Ratio (PR) as a measure of association and tested by Chi-square.

Results: As many as 70\% of women studied had high blood pressure, $76.7 \% \mathrm{had}$ poor dental conditions, and $56.7 \%$ had been chewing tobacco for $1-9$ years. Chewing tobacco increased the risk of hypertension ( $\mathrm{PR}=2.3,95 \% \mathrm{C}<1.09$ to $3.05 ; \mathrm{p}<0.028)$, diabetes $(\mathrm{PR}=2.5 ; 95 \% \mathrm{CI}<1.21$ to $3.28 ; \mathrm{p}<0.014)$, and poor dental conditions $\mathrm{RP}=3.1 ; 95 \% \mathrm{CI}<2.50$ to $4.35 ; \mathrm{p}<0.008$ ).

Conclusion: Chewing tobacco increases the risk of hypertension, diabetes, and poor dental conditions, in Batak Karo women, North Sumatra.

Keywords: tobacco chewing, health effect, Batak Karo, North Sumatera, women

\section{Correspondence:}

Ulina Karo Karo. Faculty of Public Health, Universitas Prima Indonesia.

Email: herbertwau@unprimdn.ac.id. Mobile: +6281376077718. 